\title{
PERAN PROMOSI DAN KUALITAS PELAYANAN SEBAGAI VARIABEL MODERATING DALAM KEPUTUSAN PEMBELIAN JASA KANTOR POS KOTA PALANGKA RAYA
}

\author{
Novi Angga Safitri, S.Sy. \\ Universitas Islam Sultan Agung, Semarang \\ E-mail: novianggasafitri@gmail.com
}

\begin{abstract}
ABSTRAK
Artikel ini mengkaji pengaruh citra perusahaan dan kepercayaan terhadap peningkatan keputusan pembelian jasa. Selain itu, juga mengkaji peran promosi dan kualitas pelayanan yang memoderasi pengaruh citra perusahaan dan kepercayaan terhadap peningkatan keputusan pembelian jasa. Populasi dalam artikel ini adalah seluruh pelanggan jasa Kantor Pos Kota Palangka Raya yang jumlahnya tidak diketahui sedangkan jumlah sampel sebanyak 100 orang. Teknik pemilihan sampel menggunakan purposive sampling sedangkan teknik pengambilan sampel yang digunakan adalah accidental sampling. Teknik analisis menggunakan konsep Structural Equation Modeling (SEM) dengan program Partial Least Square (PLS). Dari enam hipotesis yang diajukan, empat diterima sedangkan dua ditolak. Hasilnya yaitu citra perusahaan dan kepercayaan berpengaruh signifikan terhadap keputusan pembelian jasa. Sedangkan promosi hanya memoderasi pengaruh kepercayaan tetapi tidak memoderasi citra perusahaan terhadap keputusan pembelian jasa. Sebaliknya, kualitas pelayanan hanya memoderasi pengaruh citra perusahaan tetapi tidak memoderasi pengaruh kepercayaan terhadap keputusan pembelian jasa.
\end{abstract}

Kata Kunci: Citra Perusahaan, Kepercayaan, Promosi, Kualitas Pelayanan, Keputusan Pembelian Jasa.

\section{A. INTRODUCTION}

Belakangan ini bisnis jasa di Indonesia berkembang dengan sangat pesat. Salah satunya ialah bisnis jasa pengiriman. Bisnis jasa pengiriman senantiasa mengalami perkembangan dari waktu ke waktu. Perkembangan bisnis ini terlihat dari semakin maraknya persaingan antar para pelaku bisnis yang cukup kompetitif dalam menciptakan produk dan layanan jasa pengiriman agar mampu menarik pelanggan.

Salah satu perusahaan yang bergerak dalam bidang jasa pengiriman adalah PT Pos Indonesia. Pos Indonesia merupakan Badan Usaha Milik Negara (BUMN) yang bergerak di bidang jasa kurir, logistik, dan transaksi keuangan. PT Pos Indonesia termasuk perusahaan jasa yang sangat diperlukan kehadirannya bagi masyarakat Indonesia karena merupakan salah satu wadah penyedia sarana komunikasi bagi masyarakat terutama yang berhubungan dengan surat-menyurat maupun jasa layanan pengiriman paket barang maupun dokumen. Namun demikian, di tengah maraknya persaingan bisnis jasa pengiriman maka PT Pos Indonesia harus mampu terus meningkatkan jumlah keputusan pembelian jasa oleh para pelanggan yang selama ini telah menggunakan jasa pengiriman PT Pos 
Indonesia. Hal ini dimaksudkan agar PT Pos Indonesia tetap mampu bersaing dengan perusahaan-perusahaan jasa pengiriman lainnya.

Banyak hal yang perlu diperhatikan oleh sebuah perusahaan jasa agar menarik minat calon konsumen untuk melakukan keputusan pembelian jasa yang perusahaan tersebut tawarkan. Salah satunya yaitu citra perusahaan jasa pengiriman itu sendiri. Apabila citra perusahaan dinilai baik maka akan menimbulkan keputusan seseorang untuk melakukan pembelian terhadap jasa yang ditawarkan oleh perusahaan yang dimaksud. Selain citra perusahaan, kepercayaan juga merupakan faktor yang mempengaruhi keputusan pembelian jasa. Menurut Moorman dalam Tugiso (2016) kepercayaan adalah kemauan seseorang untuk bertumpu pada orang lain dimana kita memiliki keyakinan padanya. Ketika seseorang mengambil suatu keputusan, ia akan lebih memilih keputusan berdasarkan pilihan dari orang-orang yang lebih dapat ia percaya dari pada yang kurang dipercayai. Kepercayaan adalah faktor penting yang dapat mengatasi krisis dan kesulitan antara rekan bisnis selain itu juga merupakan aset penting dalam mengembangkan hubungan jangka panjang antar organisasi. Hubungan jangka panjang akan meningkatkan tingkat kepercayaan pelanggan terhadap harapan yang akan diterima perusahaan (Donney dan Cannon, 2005), sehingga akan mengurangi kegelisahan pelanggan terhadap pelayanan yang diterima. Kepercayaan pelanggan dipengaruhi dengan apa yang telah diterima dan dialami pelanggan (customer perceived value).

Satu aspek yang tak kalah penting yang perlu diperhatikan untuk menciptakan perusahaan jasa yang banyak digunakan oleh pelanggan ialah dengan cara melakukan promosi. Dengan adanya promosi suatu jasa maka masyarakat akan lebih mengenal jasa tersebut sehingga merasa tertarik untuk memutuskan melakukan pembelian jasa di perusahaan tersebut. Selain itu kualitas pelayanan juga tidak kalah penting dalam menentukan jumlah keputusan pembelian jasa oleh pelanggan. Jika jasa yang diterima oleh konsumen dirasakan baik maka kualitas pelayanan jasa tersebut dianggap memuaskan, dan jika jasa yang diterima melampaui harapan konsumen, maka kualitas pelayanan dipersepsikan sangat baik dan berkualitas. Sebaliknya jika jasa yang diterima lebih rendah daripada yang diharapkan, maka kualitas pelayanan dipersepsikan buruk.

Mengingat pentingnya memperhatikan faktor-faktor yang mempengaruhi seseorang untuk melakukan keputusan pembelian jasa maka penulis merasa tertarik untuk meneliti tentang keputusan pembelian pada perusahaan jasa pengiriman yaitu PT Pos Indonesia. PT Pos Indonesia sudah tersebar di seluruh pelosok Indonesia dengan jumlah lebih dari 4000 kantor yang tersebar di 24.000 titik layanan dan telah mencakup 100 persen kota dan kabupaten serta telah menjangkau hampir seluruh kecamatan di tanah air. Di Kalimantan Tengah sendiri khususnya di Kota Palangka Raya terdapat beberapa Kantor Pos yang beroperasi di sana, yakni satu kantor pusat dan tiga kantor cabang yang tersebar di beberapa daerah di Kota Palangka Raya. Dari data data lalu lintas Pos Kota Palangka Raya dalam kurun waktu 5 tahun terakhir terjadi penurunan keputusan pembelian jasa (penjualan). Untuk itu dengan penelitian ini penulis mencoba untuk mencari tahu penyebab terjadinya penurunan keputusan pembelian jasa pada Kantor Pos Kota Palangka Raya. 
Selain berdasarkan permasalahan tersebut di atas, hal lain yang juga mendasari penelitian ini dilakukan ialah karena adanya research gap mengenai variabel citra perusahaan terhadap keputusan pembelian. Hasil penelitian terdahulu menunjukkan hasil yang tidak konsisten. Hasil penelitian Pratiwi (2014) menyatakan bahwa citra perusahaan mempunyai pengaruh yang signifikan terhadap keputusan pembelian, dan citra perusahaan merupakan factor yang berpengaruh dominan terhadap keputusan pembelian. Namun berbeda dengan hasil penelitian Go, et. al. (2014) yang menyatakan bahwa citra perusahaan tidak berpengaruh signifikan terhadap keputusan pembelian.

Perbedaan penelitian ini dengan penelitian sebelumnya adalah pada variabel penelitian. Dalam penelitian ini ditambahkan dua variabel moderasi yang belum terlalu banyak diteliti, yang menghubungkan antara variabel citra perusahaan, kepercayaan dan keputusan pembelian jasa yaitu variabel promosi dan kualitas pelayanan.

Berdasarkan permasalahan tersebut di atas maka rumusan masalah studi ini yaitu "Bagaimana meningkatkan keputusan pembelian jasa". Maka Quetion Research yang muncul adalah sebagai berikut :

1. Bagaimana pengaruh Citra Perusahaan terhadap Keputusan Pembelian Jasa?

2. Bagaimana pengaruh Kepercayaan terhadap Keputusan Pembelian Jasa?

3. Bagaimana pengaruh Citra Perusahaan terhadap Keputusan Pembelian Jasa dimoderasi oleh promosi?

4. Bagaimana pengaruh Kepercayaan terhadap Keputusan Pembelian Jasa dimoderasi oleh Promosi?

5. Bagaimana pengaruh Citra Perusahaan terhadap Keputusan Pembelian Jasa dimoderasi oleh Keputusan Pelayanan?

6. Bagaimana pengaruh Kepercayaan terhadap Keputusan Pembelian Jasa dimoderasi oleh Keputusan Pelayanan?

\section{B. LITERATURE REVIEW}

\section{Keputusan Pembelian Jasa}

Pengambilan keputusan merupakan suatu kegiatan individu yang secara langsung terlibat dalam mendapatkan dan mempergunakan barang yang ditawarkan. Kotler dan Keller (2008) memaparkan ada lima tahapan dalam proses pengambilan keputusan pembelian, yaitu Pengenalan Masalah (Problem Recognition), Pencarian Informasi, Penilaian Alternatif, Keputusan Membeli serta Perilaku Setelah Pembelian. Sedangkan yang dimaksud dengan keputusan pembelian jasa ialah keputusan konsumen untuk menggunakan sebuah jasa yang ditawarkan. Menurut Astuti (2007) dalam Ghoniyah (2013) ada tiga indikator keputusan pembelian, yaitu: Kemantapan, Keyakinan dan Waktu yang singkatuntuk memutuskan.

\section{Citra Perusahaan}

Setiap perusahaan pasti mempunyai citra di mata publiknya, citra tersebut dapat dipersepsikan berbeda oleh setiap orang tergantung pada persepsi yang dilihat mereka mengenai perusahaan tersebut.Citra dapat berdampak positif maupun 
negatif. Citra perusahaan yang didapat oleh perusahaan karena adanya keunggulankeunggulan yang ada pada perusahaan tersebut, sehingga perusahaan akan bisa mengembangkan dirinya menciptakan hal-hal yang baru lagi bagi pemenuhan kebutuhan dan keinginan konsumen (Putra, et. al. 2015). Jadi yang dimaksud dengan citra perusahaan dalam penelitian ini ialah kesan yang ada dipikiran masyarakat tentang suatu perusahaan jasa pengiriman, baik dalam hal produk jasa yang ditawarkan maupun atas pelayanan yang diberikan. Dengan begitu apabila citra perusahaan dinilai baik maka akan menimbulkan keputusan seseorang untuk melakukan pembelian terhadap jasa yang ditawarkan oleh perusahaan yang dimaksud. Menurut Harrison (2007) dalam Yudiana (2016) ada empat indikator dari citra perusahaan, yakni Personality, Reputation, Value dan Corporate Identity.

Hasil penelitian terdahulu oleh Pratiwi (2014) menyatakan bahwa citra perusahaan mempunyai pengaruh yang signifikan terhadap keputusan pembelian, dan citra perusahaan merupakan faktor yang berpengaruh dominanan terhadap keputusan pembelian. Namun berbeda dengan hasil penelitian Go (2014) yang menyatakan bahwa citra perusahaan tidak berpengaruh signifikan terhadap keputusan pembelian. Berdasarkan uraian di atas, maka hipotesis yang diajukan adalah:

\section{H1: Bila citra perusahaan semakin tinggi, maka keputusan pembelian akan semakin meningkat.}

\section{Kepercayaan}

Kepercayaan adalah rasa yakin yang timbul terhadap suatu pihak untuk melakukan suatu kewajiban sesuai dengan apa yang diharapkan. Demikian halnya dengan kepercayaan yang timbul pada suatu perusahaan jasa pengiriman akan menimbulkan keputusan seseorang untuk melakukan transaksi pengiriman suatu barang menggunakan jasa perusahaan pengiriman tersebut atau dengan kata lain melakukan keputusan pembelian jasa. Indikator menurut Mayer, et. al (1995) dalam Bilondatu (2013) yaitu: Jaminan keamanan dan keselamatan pengguna, Konsisten, Kompensasi kerugian dan Reputasi.

Hasil penelitian terdahulu oleh Mahkota, et. al. (2014) menyatakan bahwa kepercayaan berpengaruh signifikan terhadap keputusan pembelian. Begitu pula dengan hasil penelitian yang dilakukan oleh Ardyanto, et. al. (2015) yang menyatakan bahwa kepercayaan berpengaruh signifikan dan merupakan faktor yang berpengaruh dominanan terhadap keputusan pembelian. Berdasarkan uraian di atas, maka hipotesis yang diajukan adalah:

\section{H2: Bila kepercayaan pelanggan semakin tinggi, maka keputusan pembelian akan semakin meningkat.}

\section{Promosi}

Faktor yang berperan penting dalam memasarkan produk perusahaan dan sekaligus menjalani komunikasi yang cukup erat dengan masyarakat sehubungan dengan produk tersebut adalah promosi (Muanas, 2014). Tan (2011) menyatakan bahwa promosi berkaitan dengan berbagai kegiatan yang dilakukan perusahaan 
untuk mencoba menyusun komunikasi antara kebaikan produknya dan membujuk para pelanggan serta konsumen untuk membeli produk itu. Promosi yang dimaksud dalam artikel ini yaitu aktivitas menyampaikan manfaat maupun kelebihankelebihan dari sebuah jasa sebagai upaya membujuk pelanggan untuk menggunakan jasa tersebut. Indikator promosi promosi menurut Kotler (2000) dalam Weenas (2013), adalah: Advertising (Periklanan), Sales Promotion (Promosi Penjualan) ,Public Relation (Hubungan Masyarakat), Personal Selling (Penjualan Personal), Direct marketing (Penjualan Langsung).

Penelitian terdahulu oleh Alessandri (2009) dalam Rifa'i (2015) menyatakan bahwa citra perusahaan akan terangkat dengan adanya promosi. Selain itu, hasil penelitian oleh Monintja, dkk (2015) menyatakan bahwa promosi mempunyai pengaruh yang signifikan terhadap keputusan pembelian. Sedangkan hasil penelitian yang dilakukan oleh Putra, et. al. (2015) menyatakan bahwa promosi tidak berpengaruh signifikan terhadap keputusan pembelian. Berdasarkan uraian di atas, maka hipotesis yang diajukan adalah:

\section{H3: Semakin tinggi citra dan promosi maka semakin tinggi keputusan pembelian jasa.}

Hasil penelitian terdahulu oleh Erwinsyah Putra (2015) yang menyatakan bahwa promosi berpengaruh signifikan terhadap kepercayaan merek. Menurut Lau dan Lee (1999) dalam Erwinsyah Putra (2015) terdapat tiga faktor yang mempengaruhi kepercayaan terhadap merek, yaitu merek itu sendiri, perusahaan pembuat merek, dan konsumen. Dan yang dimaksud kepercayaan di dalam artikel ini ialah kepercayaan terhadap perusahaan. Berdasarkan hasil penelitian tersebut maka dapat disimpulkan bahwa semakin baik promosi yang dilakukan oleh sebuah perusahaan maka semakin tinggi pula kepercayaan pelanggan terhadap perusahaan tersebut.Penelitian Daud (2013) dan Mandey, et. al (2013) juga menyatakan bahwa promosi berpengaruh signifikan terhadap keputusan pembelian. Berdasarkan uraian di atas, maka hipotesis yang diajukan adalah:

H4: Semakin tinggi kepercayaan dan promosi maka semakin tinggi keputusan pembelian jasa.

\section{Kualitas Pelayanan}

Menurut Tjiptono (2006), kualitas pelayanan merupakan suatu kondisi dinamis yang berpengaruh dengan produk, jasa, manusia, proses dan lingkungan yang memenuhi atau melebihi harapan. Sehingga definisi kualitas pelayanan dapat diartikan sebagai upaya mengimbangi harapan konsumen. Kualitas Pelayanan (service quality) dapat diketahui dengan cara membandingkan persepsi para konsumen atas pelayanan yang nyata-nyata mereka terima dengan pelayanan yang sesungguhnya mereka harapkan terhadap atribut-atribut pelayanan suatu perusahaan. Jika jasa yang diterima oleh konsumen dirasakan baik maka kualitas pelayanan jasa tersebut dianggap memuaskan, dan jika jasa yang diterima melampaui harapan konsumen, maka kualitas pelayanan dipersepsikan sangat baik 
dan berkualitas.Sebaliknya jika jasa yang diterima lebih rendah daripada yang diharapkan, maka kualitas pelayanan dipersepsikan buruk.

Berdasarkan pendapat di atas maka dapat ditarik kesimpulan tentang definisi kualitas pelayanan yaitu nilai pelayanan yang diberikan oleh suatu perusahaan demi terpenuhinya harapan atau ekspektasi dari pelanggan atas suatu jasa di perusahaan tersebut. Kualitas pelayanan menjadi salah satu faktor yang berperan menjadi salah satu alasan seseorang untuk melakukan keputusan pembelian khususnya terhadap keputusan pembelian jasa. Dalam rangka untuk menciptakan keputusan pembelian pelanggan pada produk jasa maka secara langsung terkait erat dengan dimensi kualitas jasa yang ditawarkan oleh perusahaan. Ada 5 dimensi kualitas jasa menurut Tjiptono (2008) sebagaimana dikutip oleh Kansil, et. al. (2014) yaitu bukti fisik atau bukti langsung (tangibles), kehandalan (reliability), daya tanggap (responsiveness), jaminan (assurance), dan empati (empathy).

Berdasarkan hasil penelitian Saidani, et. al. (2015) diketahui bahwa terdapat pengaruh signifikan antara kualitas pelayanan terhadap citra perusahaan. Dengan kata lain bahwa dengan mempertahankan kualitas pelayanan maka sekaligus akan meningkatkan peran citra perusahaan secara otomatis di mata para pelanggan. Penelitian Siow (2013) juga menyatakan bahwa kualitas pelayanan berpengaruh signifikan terhadap keputusan pembelian baik secara parsial maupun simultan. Berdasarkan uraian di atas, maka hipotesis yang diajukan adalah:

\section{H5: Semakin tinggi citra perusahaan dan kualitas pelayanan maka semakin tinggi keputusan pembelian jasa.}

Hasil penelitian terdahulu oleh Pramana (2016) yang menyatakan bahwa kualitas pelayanan berpengaruh signifikan terhadap kepercayaan. Hal ini berarti semakin baik kualitas pelayanan yang diberikan oleh sebuah perusahaan maka semakin tinggi pula kepercayaan yang dimiliki oleh pelanggan terhadap perusahaan tersebut. Penelitian SA (2015) juga menyatakan bahwa kualitas pelayanan berpengaruh signifikan terhadap keputusan pembelian. Berdasarkan uraian di atas, maka hipotesis yang diajukan adalah:

H6: Semakin tinggi kepercayaan dan kualitas pelayanan maka semakin tinggi keputusan pembelian jasa.

Berdasarkan kajian teori dan review hasil penelitian terdahulu, maka disusun kerangka pemikiran teoritis dalam penelitian ini digambarkan sebagai berikut

\section{Gambar 2:}

\section{Model Empirik Penelitian}

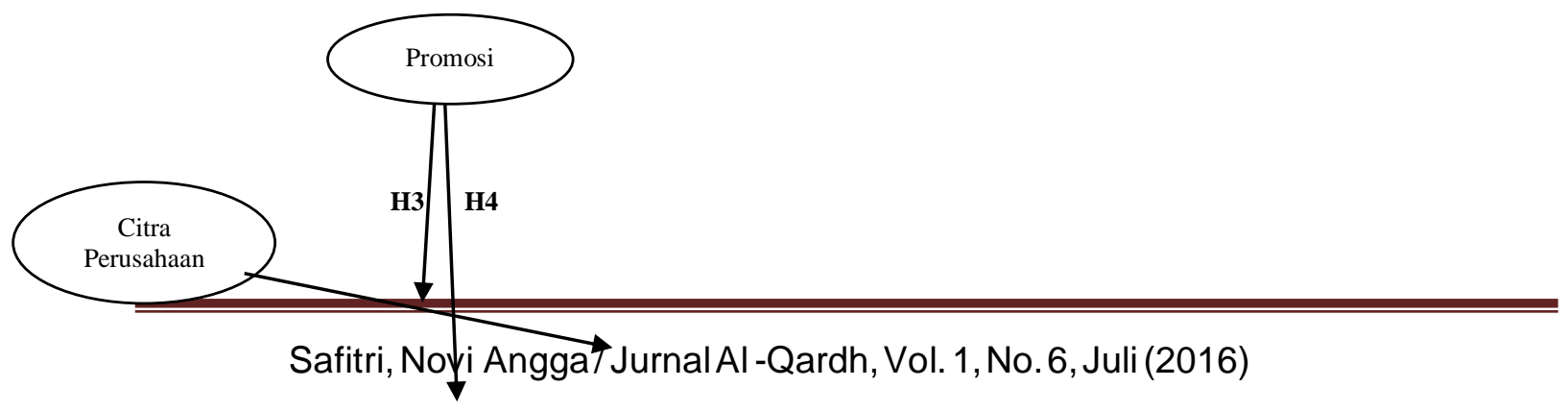




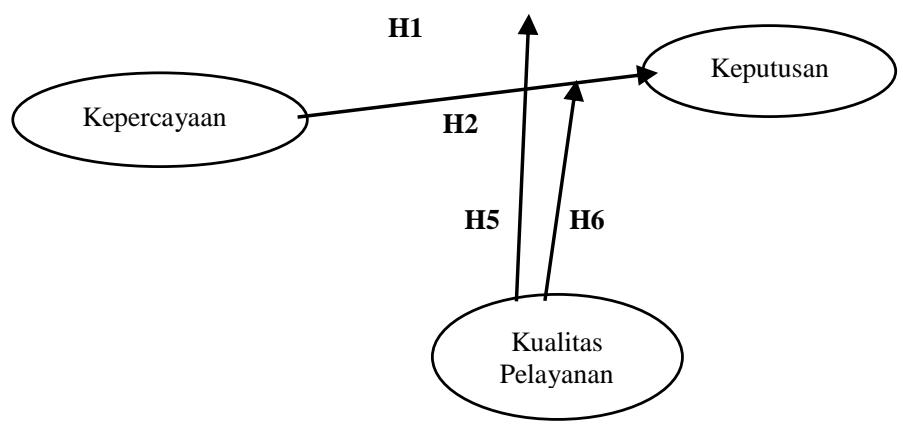

\section{METHOD RESEARCH}

Populasi dalam artikel ini yaitu seluruh pelanggan jasa Kantor Pos Kota Palangka Raya yang jumlah tidak diketahui. Besarnya sampel yang digunakan dalam penelitian ini sebanyak 100 orang. Metode yang digunakan dalam pemilihan sampel yang digunakan adalah purposive sampling dan teknik pengambilan sampel yang digunakan adalah accidental sampling. Sedangkan teknik analisis yang digunakan dalam artikel ini ialah menggunakan konsep Structural Equation Modeling (SEM) dengan program Partial Least Square (PLS).

Sumber data di dalam artikel ini terbagi menjadi dua, yaitu data primer dan data sekunder. Data primer merupakan data yang dikumpulkan sendiri oleh peneliti langsung dari sumber pertama atau tempat objek penelitian dilakukan (Siregar, 2014). Data ini diambil berdasarkan kuesioner yang dibagikan kepada responden. Jadi data primer dalam penelitian ini adalah tanggapan responden terhadap variabel penelitian. Sedangkan data sekunder merupakan data yang diterbitkan atau digunakan oleh organisasi yang bukan pengolahnya (Siregar, 2014). Data sekunder dalam penelitian ini ialah majalah-majalah, laporan instansi terkait maupun dari literatur-literatur yang ada meliputi: profil organisasi, jumlah transaksi pada Kantor Pos Kota Palangka Raya dan lain-lain.

Variabel penelitian dalam studi ini mencakup 1).Keputusan Pembelian Jasa dengan indikator kemantapan, keyakinan dan waktu yang singkat untuk memutuskan. 2). Citra perusahaan dengan indikator personality, reputation, value dan corporate identity. 3). Kepercayaan dengan indikator jaminan keamanan dan keselamatan pengguna, konsisten, kompensasi kerugian dan reputasi. 4). Promosi dengan indikator periklananan, promosi penjualan, hubungan masyarakat, penjualan personal dan penjualan langsung. 5). Kualitas pelayanan dengan indikator bukti langsung/bukti fisik, kehandalan, daya tanggap, jaminan dan empati.

Teknik analisis yang digunakan dalam penelitian ini menggunakan konsep Structural Equation Modeling (SEM) dengan program Partial Least Square (PLS). Analisis Partial Least Square (PLS) adalah metode analisis powerful karena tidak harus mengasumsikan data dengan pengukuran tertentu, dapat diterapkan pada semua skala data, tidak membutuhkan banyak asumsi dan ukuran sampel (Ghozali, 2008). 


\section{RESULTS AND DISCUSSION}

\section{Pengujian Outer Model}

\section{- Uji Validitas}

Uji validitas digunakan untuk mengukur valid atau tidaknya suatu kuesioner.

a. Convergent Validity

Dalam penelitian ini akan digunakan batas loading factor sebesar 0.5. Berdasarkan hasil uji menggunakan SmartPLS 3 pada Tabel 1 diketahui bahwa semua indikator pada variabel Citra Perusahaan, Kepercayaan, dan Keputusan Pembelian Jasa memiliki factor loading di atas 0.5. Artinya semua indikator variabel dalam penelitian ini dikatakan valid sehingga dapat digunakan dalam penelitian.

b. Discriminant Validity

Dapat diketahui bahwa korelasi konstruk Citra Perusahaan, Kepercayaan dan Keputusan Pembelian Jasa dengan masing-masing indikatornya lebih tinggi di atas 0.5 , sehingga konstruk dalam model yang diestimasi memenuhi criteria discriminant validity. Adapun metode lain untuk melihat discriminant validity adalah dengan melihat Square Root of Average Variance Extracted (AVE). Nilai yang disarankan adalah diatas 0.5. Berikut adalah nilai AVE dalam penelitian ini:

Tabel 1. Average Variance Extracted (AVE)

\begin{tabular}{|l|l|l|}
\hline & \multicolumn{1}{|c|}{ AVE } & $\sqrt{\text { AVE }}$ \\
\hline Citra Perusahaan & 0,477749 & 0,691 \\
\hline Kepercayaan & 0,537084 & 0,732 \\
\hline $\begin{array}{l}\text { Keputusan } \\
\text { Pembelian Jasa }\end{array}$ & 0,578958 & 0,760 \\
\hline
\end{tabular}

Tabel di atas menunjukan nilai $\sqrt{ }$ AVE di atas 0.5 untuk semua konstruk yang terdapat pada model penelitian, sehingga dapat disimpulkan bahwa seluruh indikator dalam penelitian ini dinyatakan valid. Nilai $\sqrt{\text { AVE }}$ yang paling rendah adalah sebesar 0,691 yaitu pada Citra Perusahaan.

- Uji Reliabilitas

Uji reliabilitas dilakukan dengan melihat nilai composite reability dari blok indikator yang mengukur konstruk. Hasil composite reability akan menunjukkan nilai yang memuaskan jika di atas 0.7 . Berikut adalah nilai composite reability dari output SmartPLS 3:

Tabel 2. Composite Reliability

\begin{tabular}{|l|lllllll|}
\hline & \multicolumn{6}{|l|}{ Composite Reliability } \\
\hline Citra Perusaha an & 0, & 7 & 7 & 9 & 4 & 7 & 1 \\
\hline Ke pe r c a y a a n & 0, & 8 & 2 & 0 & 4 & 1 & 4 \\
\hline Keputusan Pembelian Jasa & 0, & 8 & 0 & 1 & 8 & 3 & 9 \\
\hline
\end{tabular}


Tabel 2 menunjukkan bahwa nilai composite reability untuk semua konstruk adalah di atas 0.7 yang menunjukkan bahwa semua konstruk pada model yang diestimasi memenuhi ktiteria reliabel sehingga dapat digunakan dalam proses penelitian selanjutnya.

\section{Pengujian Inner Model (Struktural Model)}

Gambar 2:

Model Struktural Sebelum Moderasi

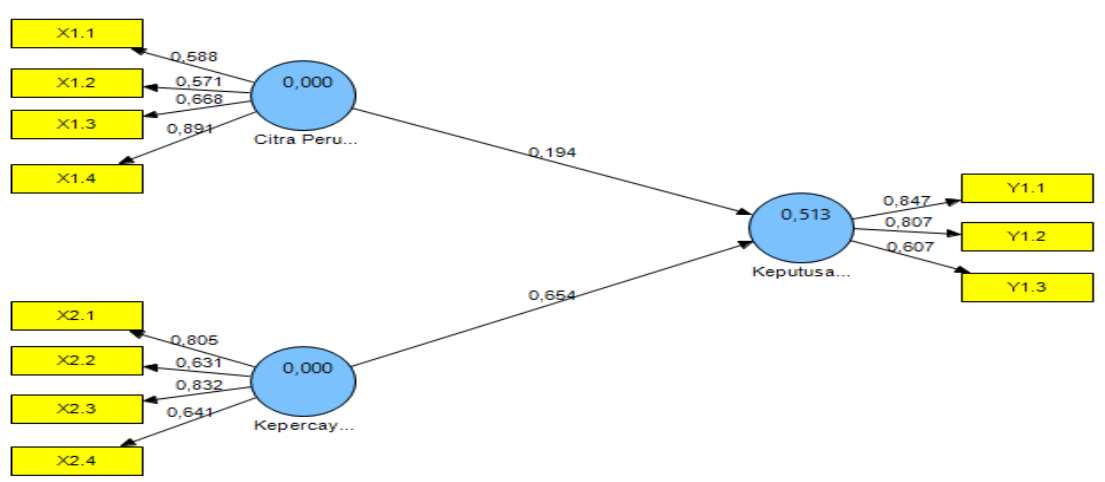

Melihat R-Square dapat mengukur seberapa baik nilai observasi yang dihasilkan oleh model dan juga estimasi parameternya. Nilai R-Square $>0$ menunjukkan bahwa mempunyai prediktif relevan, sedangkan apabila nilai R-Square $<0$ menunjukkan bahwa model kurang mempunyai prediktif relevan.

Tabel 3. $R$-square

\begin{tabular}{|c|c|}
\hline & R $\mathrm{Square}$ \\
\hline Citra Peru & \\
\hline K e p e r c a y a a n & \\
\hline Keputusan Pembelia & 0,512852 \\
\hline
\end{tabular}

Tabel 3 menunjukan nilai $R$-square konstruk Keputusan Pembelian Jasa sebesar 0,512852 yang berarti bahwa Citra Perusahaan dan Kepercayaan mampu menjelaskan varians Keputusan Pembelian Jasa sebesar 51.2\% dan selebihnya (48.8\%) dipengaruhi oleh faktor lain yang tidak diteliti dalam penelitian ini.

\section{Pengujian Hipotesis}


Untuk menentukan suatu hipotesis diterima atau ditolak, maka dilakukan dengan membandingkan antara $t_{\text {statistik }}$ dan $t_{\text {tabel }}$ dengan syarat jika $t_{\text {statistik }}>t_{\text {tabel, }}$, maka hipotesis diterima. Untuk lebih jelasnya dapat dilihat pada Tabel berikut ini:

Tabel 4. Path Coefficients Sebelum Moderasi

\begin{tabular}{|l|c|c|}
\hline & $\begin{array}{c}\text { Original } \\
\text { Sample }\end{array}$ & $\begin{array}{c}\text { T } \\
\text { Statistics }\end{array}$ \\
\hline $\begin{array}{l}\text { Citra Perusahaan } \rightarrow \\
\text { Keputusan } \\
\text { Pembelian Jasa }\end{array}$ & 0,193743 & $\mathbf{4 , 6 3 4 8 5 0}$ \\
\hline $\begin{array}{l}\text { Kepercayaan } \\
\text { T Keputusan } \\
\text { Pembelian Jasa }\end{array}$ & 0,654212 & $\mathbf{2 7 , 5 9 1 3 6 2}$ \\
\hline
\end{tabular}

Dalam rangka untuk mengetahui bahwa Promosi dan Kualitas Pelayanan dapat menjadi variabel moderator dalam memoderasi hubungan antara Citra Perusahaan, Kepercayaan dan Keputusan Pembelian Jasa, maka dapat diamati melalui hasil olahan SmartPLS 3 berikut ini:

Gambar 3:

Model Struktural Setelah Moderasi

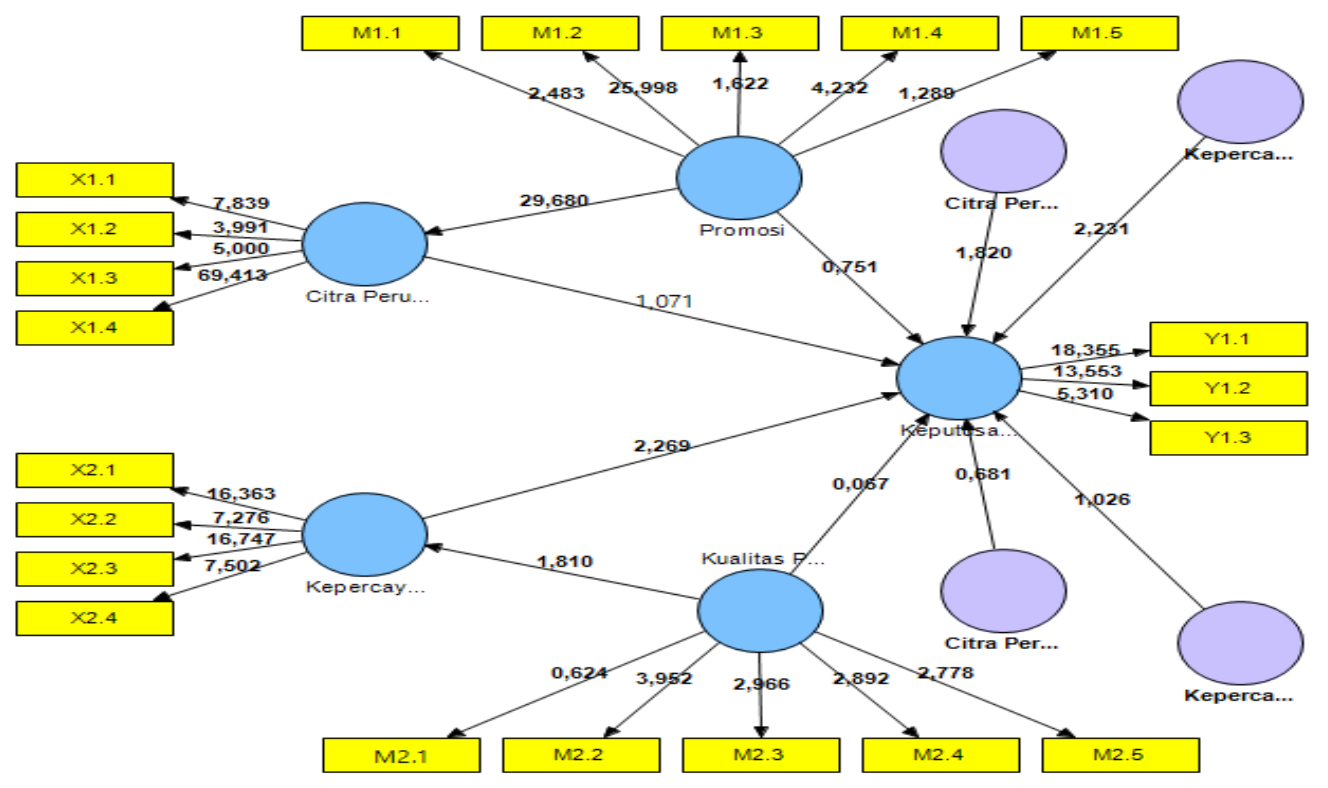

Selanjutnya hasil path coefficients setelah dilakukan analisis moderasi adalah sebagai berikut:

Tabel 5: Path Coefficients Setelah Moderasi 


\begin{tabular}{|l|c|c|}
\hline & $\begin{array}{l}\text { Original } \\
\text { Sample }\end{array}$ & T Statistics \\
\hline $\begin{array}{l}\text { Citra Perusahaan* } \\
\text { Promosi } \\
\rightarrow \text { Keputusan } \\
\text { Pembelian Jasa }\end{array}$ & 0.638178 & $\mathbf{1 . 3 6 1 0 9 2}$ \\
\hline $\begin{array}{l}\text { Kepercayaan* } \\
\text { Promosi } \\
\rightarrow \text { Keputusan } \\
\text { Pembelian Jasa }\end{array}$ & 1.079508 & $\mathbf{1 . 7 5 8 5 4 8}$ \\
\hline $\begin{array}{l}\text { Citra Perusahaan * } \\
\text { Kualitas Pelayanan } \rightarrow \\
\text { Keputusan Pembelian } \\
\text { Jasa }\end{array}$ & 0.861035 & $\mathbf{2 . 1 9 1 7 5 0}$ \\
\hline $\begin{array}{l}\text { Kepercayaan* } \\
\text { Kualitas Pelayanan } \\
\rightarrow \text { Keputusan } \\
\text { Pembelian Jasa }\end{array}$ & 0,008066 & $\mathbf{0 . 0 2 6 2 9 3}$ \\
\hline
\end{tabular}

Berdasarkan uji hubungan antar konstruk, maka hipotesis yang diajukan dalam penelitian ini dapat dijelaskan secara ringkas sebagai berikut:

Tabel 6: Ringkasan Hasil Pengujian Hipotesis

\begin{tabular}{|c|l|l|c|}
\hline Hipotesis & \multicolumn{1}{|c|}{ Pernyataan Hipotesis } & Hasil Pengujian & Koefisien Regresi \\
\hline Hipotesis 1 & $\begin{array}{l}\text { Bila citra perusahaan semakin } \\
\text { tinggi, maka keputusan } \\
\text { pembelian akan semakin } \\
\text { meningkat }\end{array}$ & $\begin{array}{l}\text { T Statistics } \\
4.634850 \\
\text { Diterima/ } \\
\text { signifikan }\end{array}$ & 0.194 \\
\hline Hipotesis 2 & $\begin{array}{l}\text { Bila kepercayaan semakin } \\
\text { tinggi, maka keputusan } \\
\text { pembelian akan semakin } \\
\text { meningkat }\end{array}$ & $\begin{array}{l}\text { T Statistics } \\
27.591362 \\
\text { Diterima/ } \\
\text { signifikan }\end{array}$ & \\
& $\begin{array}{l}\text { Semakin tinggi citra dan } \\
\text { promosi maka semakin tinggi } \\
\text { keputusan pembelian jasa }\end{array}$ & $\begin{array}{l}\text { T Statistics } \\
1.361092 \\
\text { Ditolak/ tidak } \\
\text { signifikan }\end{array}$ & \\
\hline Hipotesis 3 & $\begin{array}{l}\text { T Statistics }= \\
1.758548 \\
\text { Diterima/ } \\
\text { signifikan }\end{array}$ & \\
\hline & $\begin{array}{l}\text { Semakin tinggi kepercayaan } \\
\text { dan promosi maka semakin } \\
\text { tinggi keputusan pembelian } \\
\text { jasa }\end{array}$ & & \\
& & & \\
\hline
\end{tabular}

PEMBAHASAN 


\begin{tabular}{|l|l|l|c|}
\hline Hipotesis 5 & $\begin{array}{l}\text { Semakin tinggi citra } \\
\text { perusahaan dan kualitas } \\
\text { pelayanan maka semakin } \\
\text { tinggi keputusan pembelian } \\
\text { jasa }\end{array}$ & $\begin{array}{l}\text { T Statistics } \\
2.191750 \\
\text { Diterima/ } \\
\text { signifikan }\end{array}$ & 0.861 \\
\hline Hipotesis 6 & $\begin{array}{l}\text { Semakin tinggi kepercayaan } \\
\text { dan kualitas pelayanan maka } \\
\text { semakin tinggi keputusan } \\
\text { pembelian jasa }\end{array}$ & $\begin{array}{l}\text { T Statistics }= \\
0.026293 \\
\text { Ditolak/ tidak } \\
\text { signifikan }\end{array}$ & 0.008 \\
\hline
\end{tabular}

\section{Citra Perusahaan Berpengaruh Signifikan terhadap Keputusan Pembelian Jasa}

Hasil pengujian hipotesis membuktikan bahwa Citra Perusahaan (dengan indikator Personality, Reputation, Value, dan Corporate Identity) dapat meningkatkan secara signifikan Keputusan Pembelian Jasa(dengan indikator Kemantapan, Keyakinan, dan Waktu yang singkat untukmemutuskan)di Kantor Pos Kota Palangka Raya. Artinya bahwa, untuk meningkatkan keputusan pembelian jasa yang tinggi, maka Satuan Kerja Kantor Pos Kota Palangka Raya yang ada di Kota Palangka Raya perlumendorong dan menfasilitasi terciptanya citra perusahaan Kantor Pos Kota Palangka Rayasecara baik dan tepat di benak para pelanggan pos. Hal ini bertujuan untuk membentuk citra perusahaan Kantor Pos Palangka Raya sebagai perusahaan jasa pengiriman yang terpercaya dan profesional sehingga pelanggan akan merasa yakin dan mantap untuk menggunakan jasa Kantor Pos Kota Palangka Raya.

Hal-hal yang perlu dilakukan oleh Kantor Pos Kota Palangka Raya ialah dengan cara menciptakan karakteristik perusahaan jasa yang terpercaya dan profesional dengan selalu memastikan bahwa paket yang dikirimkan selalu sampai tujuan dengan baik serta senantiasa terus meningkatkan promosi serta memperluas jangkauan pelayanan jasa Kantor Pos di seluruh pelosok Indonesia. Hal tersebut akan membuat reputasi Kantor Pos Kota Palangka Raya sebagai perusahaan jasa pengiriman yang terpercaya meskipun dengan biaya yang murah. Dengan demikian akan terbentuk citra perusahaan jasa Kantor Pos Kota Palangka Raya sebagai perusahaan jasa pengiriman yang baik di benak pelanggan.

\section{Kepercayaan Berpengaruh Signifikan terhadap Keputusan Pembelian Jasa}

Hasil pengujian hipotesis membuktikan bahwa Kepercayaan (dengan indikator Jaminan keamanan dan keselamatan pengguna, Konsisten, Kompensasi kerugian dan Reputasi) dapat meningkatkan secara signifikan Keputusan Pembelian Jasa (dengan indikator Kemantapan, Keyakinan, dan Waktu yang singkat untuk memutuskan)di Kantor Pos Kota Palangka Raya. Artinya bahwa untuk meningkatkan Keputusan Pembelian Jasa secara terus menerus, maka Satuan Kerja Kantor Pos Kota Palangka Raya perlu memfasilitasi terciptanya kepercayaan para pelanggan terhadap jasa pengiriman Kantor Pos Kota Palangka Raya.

Menciptakan kepercayaan pelanggan dapat dilakukan dengan cara memberikan jaminan keamanan dan keselamatan pengguna dalam hal ini yaitu 
memberikan jaminan bahwa paket berupa surat, uang maupun barang yang dikirimkan melalui Jasa Kantor Pos Kota Palangka Raya selalu sampai tujuan dengan tepat dan aman serta sesuai dengan keinginan pelanggan. Selain itu dengan cara melakukan pelayanan yang konsisten yaitu tidak memberikan pelayanan yang berbeda pada pelanggan dari kalangan manapun, selalu tepat waktu dan selalu konsisten memberikan pelayanan dengan harga terjangkau. Serta adanya jaminan ganti rugi apabila terjadi masalah juga berperan serta sebagai faktor pendukung terciptanya kepercayaan di benak para pelanggan.

\section{Promosi Tidak Memoderasi Hubungan antara Citra Perusahaan dan Keputusan Pembelian Jasa}

Hasil pengujian hipotesis membuktikan bahwa Promosi (dengan indikator Periklanan, Promosi Penjualan, Hubungan Masyarakat, Penjualan Personal, dan Penjualan Langsung) tidak dapat memoderasi ataupun memperkuat pengaruh Citra Perusahaan (dengan indikator Personality, Reputation, Value dan Corporate Identity) terhadap Keputusan pembelian jasa (dengan indikator Keyakinan, Kemantapan, dan Waktu yang singkat untuk memutuskan) di Kantor Pos Kota Palangka Raya. Artinya adanya Promosi jasa pengiriman Kantor Pos Palangka Raya tidak mampu memperkuat maupun menjadi variabel moderator tatkala perusahaan sudah mampu menciptakan Citra Perusahaan yang baik di benak parak pelanggan.

Hasil penelitian ini berbeda dengan hasil penelitian terdahulu oleh Alessandri (2009) dalam Rifa'i (2015) menyatakan bahwa citra perusahaan akan terangkat dengan adanya promosi. Hal ini dikarenakan objek dalam penelitian Alessandri (2009) adalah acara superbowl di Amerika.Hasil risetnya menemukan bahwa kekuatan acara Superbowl sangat menarik para pengiklan untuk beriklan dalam acara itu. Acara tersebut diyakini pengiklan akan memperkuat citra perusahaan. Iklan-iklan khusus diciptakan para perusahaan hanya untuk acara Superbowl. Rating acara tersebut yang sangat tinggi selama bertahun-tahun membuat banyak perusahaan rela membayar mahal untuk beriklan diacara tersebut. Temuan penelitian ini adalah citra perusahaan akan terangkat ketika promosi yang dilakukan pada acara Superbowl ditonton ribuan orang Amerika. Hal ini jelas berbeda dengan objek penelitian yang diteliti oleh peneliti, yaitu perusahaan jasa Kantor Pos Kota Palangka Raya yang melakukan promosi perusahaannya lebih dominan di media cetak dan berbagai jenis promosi penjualan lainnya, bukan dengan memasang iklan di acara televisi yang sedang booming secara live.

\section{Promosi Memoderasi Hubungan antara Kepercayaan dan Keputusan Pembelian Jasa}

Hasil pengujian hipotesis membuktikan bahwa Promosi (dengan indikator Periklanan, Promosi Penjualan, Hubungan Masyarakat, Penjualan Personal, dan Penjualan Langsung) dapat memoderasi Kepercayaan (dengan indikator Jaminan keamanan dan keselamatan pengguna, konsisten, kompensasi kerugian dan Reputasi) terhadap Keputusan Pembelian Jasa (dengan indikator Keyakinan, Kemantapan, dan Waktu yang singkat untuk memutuskan) di Kantor Pos Kota Palangka Raya. Artinya melalui adanya Promosi jasa pengiriman Kantor Pos 
Palangka Raya secara intens, maka hal tersebut akan menanamkan Kepercayaan terhadap Kantor Pos Kota Palangka Raya yang baik di benak parak pelanggan sehingga akan semakin meningkatkan Keputusan pembelian jasa terhadap perusahaan jasa pengiriman Kantor Pos Kota Palangka Raya.

Salah satu bentuk promosi Kantor Pos Kota Palangka Raya ialah dengan cara memasang iklan di tv, media cetak maupun spanduk. Kantor Pos Kota Palangka Raya seringkali juga memberikan beberapa souvenir cantik kepada pelanggannya berupa pulpen, sticker dan lain-lain dalam rangka promosi penjualan jasa. Begitu pula dalam rangka memeriahkan HUT dan Hari Bakti Kantor Pos Kota Palangka Raya biasanya mengadakan undian berhadiah dalam rangka memeriahkan hari tersebut dan juga demi menjalin hubungan masyarakat dengan para pelanggan kantor pos. Bentuk promosi lainnya yaitu dengan menjadi wadah penyaluran Bantuan Langsung Tunai (BLT) dan juga Bantuan Langsung Sementara Masyarakat (BLSM) yang merupakan dana bantuan dari pemerintah untuk para rakyat yang berhak menerimanya. Promosi kantor pos Kota Palangka Raya juga dilakukan dengan cara across the counter selling yaitu layanan dan penjelasan langsung di loket yang dilakukan oleh para petugas loket, customer service dan juga security yang bertugas. Di sisi lain, kantor pos juga gencar melakukan promosi melalui media internet dan juga telepon serta brosur.

\section{Kualitas Pelayanan Memoderasi Hubungan antara Citra Perusahaan dan Keputusan Pembelian Jasa}

Hasil pengujian hipotesis membuktikan bahwa Kualitas Pelayanan (dengan indikator Bukti langsung/bukti fisik, Kehandalan, Daya tanggap, Jaminan dan Empati) dapat memoderasi atau dapat memperkuat pengaruh antara Citra perusahaan (dengan indikator Personality, Reputation, Value dan Corporate Identity) terhadap Keputusan Pembelian Jasa (dengan indikator Keyakinan, Kemantapan, dan Waktu yang singkat untuk memutuskan) di Kantor Pos Kota Palangka Raya.

Para pelanggan menilai bahwa Kantor Pos Kota Palangka Raya berada di pusat kota, gedungnya cukup bagus serta didukung dengan fasilitas yang cukup memadai (kursi tunggu, tempat parkir). Para petugas Kantor Pos Kota Palangka Raya juga dinilai cukup menguasai/ mengetahui alamat/ daerah yang dituju ketika ditanya oleh pelanggan, melayani dengan cepat, baik dan juga ramah. Selain itu petugas kantor Pos Kota Palangka Raya juga dinilai selalu melayani sesuai urutan antrian, cepat tanggap dalam melayani keinginan dan keluhan pelanggan selain itu security juga dinilai selalu cepat tanggap dalam membantu pelanggan yang kebingungan. Paket yang dikirimkan via Kantor Pos Kota Palangka Raya juga terjamin selalu sampai tujuan dan isi paket dikirim dijamin aman serta adanya jaminan ganti rugi apabila terjadi masalah. Baik petugas loket, customer service maupun security Kantor Pos Kota Palangka Raya selalu melayani pelanggan dengan baik serta selalu bersedia menjawab pertanyaan maupun keluhan pelanggan dengan baik dan senantiasa berempati menanyakan keperluan setiap pelanggan yang datang. Kualitas pelayanan yang baik akan menciptakan Citra Perusahaan yang baik di benak para pelanggan sehingga pelanggan yang merasa bahwa 
pelayanan Kantor Pos Kota Palangka Raya sangat baik akan merasa yakin dan mantap untuk melakukan Keputusan Pembelian Jasa.

\section{Kualitas Pelayanan tidak Memoderasi Hubungan antara Kepercayaan dan Keputusan Pembelian Jasa}

Hasil pengujian hipotesis membuktikan bahwa Kualitas Pelayanan (dengan indikator Bukti langsung/bukti fisik, Kehandalan, Daya tanggap, Jaminan dan Empati) tidak dapat memoderasi ataupun memperkuat hubungan antara Kepercayan (dengan indikator Jaminan keamanan dan keselamatan pengguna, konsisten, kompensasi kerugian dan Reputasi) terhadap Keputusan pembelian jasa (dengan indikator Keyakinan, Kemantapan, dan Waktu yang singkat untuk memutuskan) di Kantor Pos Kota Palangka Raya. Artinya, meskipun tanpa adanya Kualitas pelayanan, Kepercayaan akan tetap berpengaruh signifikan terhadap Keputusan pembelian jasa di Kantor Pos Kota Palangka Raya.

Hasil penelitian ini berbeda dengan hasil penelitian terdahulu oleh Pramana (2016) yang menyatakan bahwa kualitas pelayanan berpengaruh signifikan terhadap kepercayaan. Hal ini dikarenakan kriteria responden dalam penelitian Pramana (2016) didominasi oleh responden yang berusia lebih dari 35-40 tahun serta berlatarbelakang pendidikan sarjana sehingga para responden menganggap kualitas pelayanan sangat berpengaruh signifikan terhadap Kepercayaan Nasabah Bank Mandiri Cabang Veteran Denpasar-Bali. Dikarenakan responden dengan kriteria tersebut sangat menganggap penting kualitas pelayanan sebuah bank, semakin baik kualitas pelayanan maka kepercayaan mereka akan semakin meningkat. Begitu pula sebaliknya, apabila kualitas pelayanan bank dirasakan kurang baik atau kurang memuaskan hal tersebut akan menurunkan tingkat kepercayaan responden sehingga berpeluang untuk berpindah menggunakan jasa bank lain. Berbeda halnya dengan kriteria responden dalam penelitian peneliti yang didominasi oleh responden yang berusia muda (produktif) yaitu berusia 17-26 tahun dan berlatarbelakang pendidikan SMA sehingga pelanggan Kantor Pos Kota Palangka Raya lebih dapat memaklumi apabila ada kekurangan kualitas pelayanan di Kantor Pos Kota Palangka Raya terutama di Kantor Pos Cabang yang fasilitas serta pegawainya tidak sebanyak di Kantor Pos pusat sehingga terkadang para pelanggan akan mendapatkan pelayanan lebih lama karena harus mengantri cukup lama terutama di hari-hari sibuk seperti di awal bulan atau pun di awal minggu. Namun demikian, kualitas pelayanan Kantor Pos tersebut masih dapat dimaklumi oleh para pelanggan karena adanya jaminan keamanan atas paket (surat, uang maupun barang) yang dikirimkan via Kantor Pos Kota Palangka Raya sehingga pelanggan selalu mempercayai reputasi Kantor Pos Kota Palangka Raya sebagai perusahaan jasa yang professional dan terpercaya.

\section{E. CONCLUSIONS}

\section{Kesimpulan}

Penelitian ini secara umum dapat disimpulkan bahwa semakin baik Citra Perusahaan dan juga Kepercayaan di mata pelanggan maka semakin tinggi pula tingkat Keputusan Pembelian Jasa Pengiriman di Kantor Pos Kota Pos Kota 
Palangka Raya oleh para pelanggan. Promosi dinilai hanya mampu memoderasi pengaruh kepercayaan tetapi tidak memoderasi variabel citra perusahaan terhadap keputusan pembelian jasa. Hal ini dikarenakan Citra Perusahaan Kantor Pos Kota Palangka Raya sudah dianggap baik di benak para pelanggan sehingga ada maupun tidak adanya promosi itu tidak berpengaruh terhadap pilihan pelanggan untuk tetap menggunakan jasa kantor pos. Sebaliknya, kualitas pelayanan hanya memoderasi pengaruh citra perusahaan tetapi tidak memoderasi pengaruh kepercayaan terhadap keputusan pembelian jasa. Artinya meskipun ada kekurangan pada kualitas pelayanan di Kantor Pos Kota Palangka Raya terutamaketika pelanggan harus antri cukup lama terutama di hari-hari sibuk seperti di awal bulan atau pun di awal minggu para pelanggan tetap bisa memakluminya. Hal tersebut tidak mengurangi kepercayaan pelanggan untuk tetap menggunakan jasa kantor pos karena adanya jaminan keamanan atas paket yang dikirimkan via kantor pos yang selalu mampu mengirimkan paket hampir ke seluruh pelosok Indonesia, sehingga pelanggan berkeyakinan bahwa Citra Perusahaan Kantor Pos Kota Palangka Raya dinilai sebagai perusahaan jasa pengiriman yang profesional dan terpercaya.

\section{Agenda Penelitian Mendatang}

Penelitian mendatang perlu dikembangkan dalam ruang lingkup yang lebih luas yaitu dengan cara membandingkan keputusan pembelian jasa oleh pelanggan dan juga oleh para pegawai kantor pos sendiri. Penelitian mendatang perlu menambahkan variabel lain yang diduga dapat meningkatkan keputusan pembelian jasa, misalnya word of mouth, brand image, biaya, motivasi, pengalaman, serta relationship marketing.

\section{DAFTAR PUSTAKA}

Ardyanto, Denni., et. al. (2015). Pengaruh Kemudahan dan Kepercayaan Menggunakan e-commerce Terhadap Keputusan Pembelian Online (Survei Pada Konsumen www.petersaysdenim.com). Jurnal Administrasi Bisnis (JAB), Vol. 22, No. 1 Mei 2015.

Badan Pusat Statistik Kota Palangka Raya. (2015). Statistik Palangka Raya. Melalui <https://palangkakota.bps.go.id/>

Bilondatu, Machrani Rinandha. (2013). Motivasi, Persepsi, dan Kepercayaan Pengaruhnya terhadap Keputusan Pembelian Konsumen pada Sepeda Motor Yamaha di Minahasa. Jurnal EMBA Vol.1 No.3 September 2013. ISSN 2303-1174.

Daud, Deny. (2013). Promosi dan Kualitas Layanan Pengaruhnya terhadap Keputusan Konsumen Menggunakan Jasa Pembiayaan Pada PT. Bess Finance Manado. Jurnal EMBA 51 Vol.1 No.4 Desember 2013. ISSN 23031174.

Donney \& Cannon. (2005). Proses Kepercayaan. Rineka Cipta. Jakarta. 
Ghoniyah, Nunung dan Ursila Ani. (2013). Faktor-faktor Penentu Keputusan Pembelian Blackberry di Semarang. Jurnal Ekonomi Manajemen Akuntansi - ISSN 0853 - 8778 No. 34 / Th. XX / April 2013.

Go, Melisa E.B., et. al. (2014). Citra Perusahaan dan Kualitas Pelayanan Pengaruhnya terhadap Keputusan Menggunakan Jasa pada Sekolah Mengemudi Melati di Manado. Jurnal EMBA Vol.2 No.3 September 2014. ISSN 2303-1174.

Kansil, Janrilous M. dan Jantje L. Sepang. (2014). Kualitas Layanan Pengaruhnya terhadap Keputusan Menggunakan Internet di Warnet Kelurahan Kairagi II. Jurnal EMBA 201 Vol.2 No.1 Maret 2014. ISSN 2303-1174.

Kotler, Philip dan Kevin Lane Keller. (2007). Manajemen Pemasaran. Alih Bahasa Benyamin Molan, Edisi Dua Belas. Penerbit PT.Indeks. Jakarta. . (2008). Manajemen Pemasaran. Edisi ke-12. Erlangga. Jakarta.

Mandey, Jilly Bernadette. (2013). Promosi, Distribusi, Harga Pengaruhnya terhadap Keputusan Pembelian Rokok Surya Promild. Jurnal EMBA 95 Vol.1 No.4 Desember 2013. ISSN 2303-1174.

Muanas, Ahmad. (2014). Pengaruh Produk, Harga dan Promosi terhadap Keputusan Pembelian Mobil Buana Indomobil Trada. Jurnal Ilmu dan Riset $\begin{array}{llllll}\text { Manajemen } & \text { Vol. } & 3 & \text { No. } & 12 & \text { (2014). }\end{array}$ <https://ejournal.stiesia.ac.id/jirm/article/viewFile/686/657>

Pramana, I Gede Yogi \& Ni Made Rastini. (2016). Pengaruh Kualitas Pelayanan terhadap Kepercayaan Nasabah dan Loyalitas Nasabah Bank Mandiri Cabang Veteran Denpasar Bali. E-Jurnal Manajemen Unud, Vol. 5, No.1, 2016: 706-733 ISSN: 2302-8912.

Pratiwi, Made Suci., et.al. (2014). Pengaruh Citra Perusahaan, Citra Produk dan Citra Pemakai terhadap Keputusan Pembelian Produk Foremost pada Distro Ruby Soho di Singaraja. e-Journal Bisma Universitas Pendidikan Ganesha Jurusan Manajemen (Volume 2 Tahun 2014). E-Journal on-line. Melalui http://ejournal.undiksha.ac.id/index.php/JJM/article/view/4314/3338

Putra, Arfian Bimantara., et. al. (2015). Pengaruh Bauran Pemasaran Jasa Terhadap Keputusan Pembelian (Survei pada Pelanggan yang Menggunakan Jasa Pengiriman di Kantor Pos Besar Kota Malang). Jurnal Administrasi Bisnis (JAB)|Vol. 1 No. 1 Januari 2015.

Putra, Erwinsyah. (2015). Pengaruh Bauran Pemasaran Jasa terhadap Kepercayaan Merek (Brand Trust) dan Dampaknya Pada Keputusan Mahasiswa Memilih Kuliah di Politeknik Aceh. Jurnal Manajemen 
Pascasarjana Universitas Syiah Kuala. Volume 4, No. 1, Februari 2015 ISSN 2302-0199.

Putra, Gagah Bimo Setyo Putra., et. al. (2015). Pengaruh Citra Perusahaan terhadap Minat Berkunjung dan Keputusan Berkunjung (Survei pada Pengunjung Taman Rekreasi PT.Selecta, Kota Batu, Jawa Timur). Jurnal Administrasi Bisnis (JAB) | Vol. 26 No. 2 September 2015 | administrasibisnis.studentjournal.ub.ac.id.

PT Pos Indonesia (Persero). (tanpa tahun). Sekilas PT Pos Indonesia (Persero) Melalui <http://www.bumn.go.id/posindonesia/halaman/41> [27/08/16]

Rifa'i, Khamdan.. (2015). Pengaruh Promosi dan Kualitas Pelayanan terhadap Citra Perusahaan, Kepercayaan Merek, Kepuasan dan Loyalitas Pelanggan Studi pada Nasabah BRI Syariah di Banyuwangi. FENOMENA (Jurnal Penelitian Islam Indonesia). Vol. 14 No. 1 April 2015.

SA, Mimi. (2015). Pengaruh Harga, Kualitas Pelayanan, Lokasi dan Keragaman Produk terhadap Keputusan Pembelian di Ranch Market. Jurnal Ekonomi/Volume XX. No. 01 Maret 2015.

Saidani, Basrah. (2012). Pengaruh Kualitas Produk dan Kualitas Layanan terhadap Kepuasan Konsumen dan Minat Beli pada Ranch Market. Jurnal Riset Manajemen Sains Indonesia (JRMSI) |Vol. 3, No. 1, 2012.

Siow, Natalia. (2013). Kualitas Layanan dan Kepercayaan Pelanggan Pengaruhnya terhadap Keputusan Pembelian Sepeda Motor Suzuki Satria Fu150 di Kota Manado. Jurnal EMBA 1069 Vol.1 No.3 September 2013. ISSN 2303-1174.

Tan, Erwin Rediono. (2011). Pengaruh Faktor Harga, Promosi dan Pelayanan terhadap Keputusan Konsumen untuk Belanja di Alfamart Surabaya. Jurnal Kewirausahaan Volume 5 Nomor 2, Desember 2011. ISSN. 1978-4742.

Tjiptono. Handy. (2006). Manajemen Jasa. Andi Offset. Yogyakarta.

Tugiso, Ilham., et. al. (2016). Pengaruh Relationship Marketing, Keamanan, Kepercayaan dan Kualitas Pelayanan terhadap Keputusan Pembelian Online Shop dan Loyalitas Konsumen sebagai Variabel Intervening (Studi Kasus Pada Onlineshop "NUMIRA" Semarang). Journal Of Management, Volume 2 No.2 Maret 2016.

Weenas, Jackson R.S. (2013). Kualitas Produk, Harga, Promosi dan Kualitas Pelayanan Pengaruhnya terhadap Keputusan Pembelian Spring Bed Comforta. Jurnal EMBA 607 Vol.1 No.4 Desember 2013. ISSN 2303-1174. 